Boston University School of Law Scholarly Commons at Boston University School of Law

Faculty Scholarship

1996

\title{
Bringing Foucault into Law and Law into Foucault
}

Hugh Baxter

Boston Univeristy School of Law

Follow this and additional works at: https://scholarship.law.bu.edu/faculty_scholarship

Cart of the Law Commons

\section{Recommended Citation}

Hugh Baxter, Bringing Foucault into Law and Law into Foucault, 48 Stanford Law Review 449 (1996).

Available at: https://scholarship.law.bu.edu/faculty_scholarship/529

This Article is brought to you for free and open access by Scholarly Commons at Boston University School of Law. It has been accepted for inclusion in Faculty Scholarship by an authorized administrator of Scholarly Commons at Boston University School of Law. For more information, please contact lawlessa@bu.edu. 


\section{HEINONLINE}

Citation: 48 Stan. L. Rev. 449 1995-1996

Content downloaded/printed from

HeinOnline (http://heinonline.org)

Tue Dec 1 17:46:16 2009

-- Your use of this HeinOnline PDF indicates your acceptance of HeinOnline's Terms and Conditions of the license agreement available at http://heinonline.org/HOL/License

-- The search text of this PDF is generated from uncorrected OCR text.

-- To obtain permission to use this article beyond the scope of your HeinOnline license, please use:

https://www.copyright.com/ccc/basicSearch.do?

\&operation $=$ go\&search Type $=0$

\&lastSearch $=$ simple\&all=on\&titleOrStdNo=0038-9765 


\title{
REVIEW ESSAY
}

\section{Bringing Foucault into Law and Law into Foucault}

\author{
Hugh Baxter*
}

Foucault and Law: Towards a Sociology of Law as Governance. By Alan Hunti and Gary Wickham.ł London: Pluto Press. 1994. 148 pp. $\$ 18.95$.

The announced purpose of Alan Hunt and Gary Wickham's book, Foucault and Law, is "to demonstrate the pertinence of [Michel] Foucault for contemporary issues in legal studies." In this review essay, Hugh Baxter acknowledges the important contributions Hunt and Wickham have made, both in introducing basic Foucaultian concepts to a legal academic audience, and in identifying the defects in Foucault's explicit discussions of law. Yet, Baxter contends, the authors turn too quickly from Foucault's work toward their own new research project, the "sociology of law as governance." Rather than constructing a new subdiscipline of the sociology of law, Baxter argues, the authors might have considered more directly how Foucault's work could illuminate issues in contemporary legal studies. Through a critical examination of some exemplary appropriations of Foucault, Baxter suggests the possibilities and limits of Foucault's usefulness for legal scholarship.

Alan Hunt and Gary Wickham direct their book, Foucault and Law, toward two absences. The first is the relative lack of attention legal scholars have given Michel Foucault's work, despite its continuing influence in the humanities some twelve years after his death. ${ }^{1}$ The second absence, Hunt and Wickham suggest, is in Foucault's work itself, and it helps explain Foucault's indifferent reception in the legal academy. While " $\mathrm{h}] \mathrm{e}$ has a great deal to say about law and even more that has legal relevance," the authors observe, "Fou-

* Associate Professor of Law, Boston University. A.B., Stanford University, 1980; Ph.D., Yale University, 1985; J.D., Stanford University, 1990. Thanks to Jane Goldman, Pnina Lahav, Molly McUsic, Reva Siegel, Katharine Silbaugh, Manuel Utset, and especially Marina Leslie.

$\dagger$ Professor in Law and Sociology, Carleton University, Ottawa, Canada.

$\ddagger$ Lecturer in Sociology, Murdoch University, Perth, Australia.

1. P. vii. 
cault does not have a theory of law." 2 Indeed, as Hunt and Wickham argue, Foucault "tends to expel law from any major role" in modern society. ${ }^{3}$

The absence of a Foucaultian theory of law presents the central problem of Hunt and Wickham's book: If Foucault's work offers no plausible account of law, why should legal scholars take him seriously? If we seek to bring Foucault into law, must we not first bring law into Foucault?

Hunt and Wickham declare from the outset that ordinary techniques of interpretation cannot generate a Foucaultian theory of law. ${ }^{4}$ Accordingly, they draw on Foucault's work more selectively and indirectly. After introducing the concepts and themes of Foucault's work to an audience trained in law but innocent of Foucault, 5 and identifying the "expulsion of law" from his work, ${ }^{6}$ the authors use Foucault's writings only as a point of departure for "a new and fruitful approach to the exploration of legal phenomena."7 Hunt and Wickham entitle this new approach "the sociology of law as governance"s and classify it as a "subdiscipline" of the sociology of law.9 The "law as governance" approach borrows extensively from the classical sociological tradition, particularly from Durkheim and Weber. ${ }^{10}$ Thus, in Hunt and Wickham's words: "the name Foucault does not signal an intellectual revolution," but instead "an opportunity to return to some nineteenth- and early twentieth-century sociological endeavors." 11

The authors' diagnosis of Foucault's "expulsion of law" is an important accomplishment. They also deserve credit for seeing that Foucault's failure to develop an adequate theory of law presents a problem for, but does not necessarily preclude, his appropriation by contemporary legal scholars. The authors' solution to this problem - their outline of the "law as governance" approachseems to me far less satisfactory. Considered on its own terms, the governance approach has significant weaknesses. More important, the authors' presentation of their new theory deflects our attention from the book's central question: Given the inadequacy of Foucault's theory of law, how can Foucault's work nevertheless be useful to legal academics? At the end of this review, I suggest a different strategy for answering this question. Rather than develop a new theory of law, the authors might have explored exemplary appropriations of

\section{P. viii.}

3. P. 22.

4. "We stress that the neglect of Foucault cannot be made good by a mere packaging of his direct comments on matters legal. ... [N]o amount of stitching together of this material can deliver 'Foucault's theory of law.' ... Consequently, we do not set out to construct a 'Foucaultian theory of law.' " P. viii.

5. Pp. 3-36.

6. P. 56 (describing Foucault's treatment of law as "the expulsion of law from modemity"); see also pp. 55-71 (describing and criticizing Foucault's expulsion of law).

7. P. viii.

8. Pp. 77-78, 99-102.

9. Pp. 121-22.

10. See pp. 78, 92-97, 112-20 (discussing Durkheim); pp. 76, 99-100, 116 (discussing Weber). In proposing a new direction for the sociology of law, Hunt and Wickham also acknowledge the infiuence of "Machiavellian political theory" and incorporate "traces of ethnomethodological sociology and Parsonian sociology." P. 78.

11. P. 132. 
Foucault in existing legal scholarship, or considered more directly than they do how Foucault's themes and concepts might be put to work in future legal scholarship.

\section{Foucault AND the "ANalytics of Power"}

As Hunt and Wickham observe, Foucault's intellectual career defies "easy encapsulation."12 Foucault's interests and methods changed over time, and his scattered attempts to describe his own works are notoriously (and perhaps intentionally) inconsistent. ${ }^{13}$ Hunt and Wickham sensibly avoid asking whether the various phases of Foucault's work form a unity. Rather than construct an intellectual biography of a "real Foucault," Hunt and Wickham acknowledge "that there are many 'Foucaults' who coexist and interact with one another."14

Of these many Foucaults, the one Hunt and Wickham discuss in the most detail is the one best known to American readers: the Foucault of 1975 to 1977 who developed an "analytics of power" in Discipline and Punish, ${ }^{15}$ The History of Sexuality, Volume $I,{ }^{16}$ and Power/Knowledge. ${ }^{17}$ In these works, the authors argue, "[1]aw comes to the fore" and "forms a significant motif." 18 Nevertheless, they conclude, Foucault ultimately "expel[s] law from any significant role" in his account of modern power. ${ }^{19}$

In this section, I outline the central themes and concepts of Foucault's analytics of power. This account will serve as background for my discussion, in part II, of Foucault's "expulsion of law."20

12. P. 3.

13. Compare, e.g., Michel Foucault, Truth and Power, reprinted in Power/Knowledge: SELECTED INTERVIEWS AND OTHER WrITngs 1972-1977, at 109, 115 (Colin Gordon ed., Colin Gordon, Leo Marshall, John Mepham, \& Kate Soper trans., 1980) ("[W] in Madness and Civilisation or The Birth of the Clinic, but power?') with Micher Foucaunt, Critical Theory/Intellectual History, in Polmics, Philosophy, Culture: InTERviews and Other Writings, 1977-1984 at 39 (Lawrence D. Kritzman ed., Alan Sheridan trans., 1988) ("[P]ower, as an autonomous question, does not interest me. ... I am not developing a theory of power. I am working on the history ... of the way reflexivity of self upon self is established, and the discourse of truth that is linked to it.") and Michel Foucault, On the Genealogy of Ethics: An Overview of Work in Progress, in Huberr L. Dreyfus \& Paul Rabinow, Michel Foucault: Beyond Structuralism and Hermeneutics 229, 237 (2d ed. 1983) (distinguishing among truth, power, and ethics, and stating that "[t]he truth axis was studied in The Birth of the Clinic," while Madness and Civilization investigated all these axes, albeit in a somewhat confused fashion) and Michel Foucault, The Subject and Power, in DREYFus \& RABNow, supra, at 208, 209 ("[I]t is not power, but the subject, which is the general theme of my research.").

14. P. 3.

15. Mrcher Foucault, Discipline and Punsh: The Birth of the Prison (Alan Sheridan trans., Pantheon Books 1977) (1975).

16. Michel Foucault, 1 The History of Sexualtry: An INTroduction (Robert Hurley trans., Vintage Books 1990) (1976).

17. Foucaurt, POWER/KNowledGe, supra note 13 . Hunt and Wickham rely heavily on the 1975 1977 essays in id. at 78-133.

18. P. 39.

19. P. 34 .

20. My overview of Foucault is, I think, consistent with the authors' account, although not identical in detail or order of presentation. 


\section{A. The Juridical Model of Power/Law/Sovereignty}

Foucault was fond of introducing his ideas as departures from received wisdom. He adopts this strategy in developing his notion of power. While here, as elsewhere, Foucault's account of the received wisdom seems as much caricature as characterization, ${ }^{21}$ the account nonetheless proves critically important in understanding Foucault's view of law.

Foucault signals this connection to law in the name he gives the (ostensibly) traditional view of power: the "juridico-discursive"22 or "juridical" notion of power. ${ }^{23}$ In this conception, "deeply rooted in the history of the West,"24 power is purely negative and prohibitory, ${ }^{25}$ "incapable of doing anything, except to render what it dominates incapable of doing anything either."26 The form of this "power to say no,"27 Foucault says, is the legal command, issued from the sovereign power to the obedient subject. ${ }^{28}$ This model portrays power as homogenous or isomorphic, identical in its manifestations at every level of the social order. ${ }^{29}$

Foucault traces the juridical model of negative, commanding power to the triumph of the great monarchies in the sixteenth and seventeenth centuries. The monarchical power "presented itself as a referee, a power capable of putting an end to war, violence and pillage and saying no to [feudal] struggles." 30 The monarch's sovereign power was the power of law; law provided monarchical power with its "mode of manifestation and the form of its acceptability." 31 Foucault, of course, recognizes that in his own era the European monarchies exist, if at all, in form alone. Nevertheless, he argues, the form of monarchical thought - the linkage of power, law, and sovereignty - persists. In Foucault's words: "[D]espite the difference in epochs and objectives, the representation of power has remained under the spell of monarchy. In political thought and analysis, we still have not cut off the head of the king."32

Much of Foucault's work during the mid-1970s was an attempt to create a new "grid of historical decipherment" 33 that could replace the juridical model of "power-law" and "power-sovereignty."34 Using this new "grid" of con-

21. See Dreyfus \& Rabinow, supra note 13, at 127 (stating that the "repressive hypothesis" Foucault uses as a foil in The History of Sexuality "is not directly attributed to any particular individual or school. It is set up as a kind of Nietzschean parody of current received opinion.").

22. 1 Foucault, The History of SeXuality, supra note 16 , at 82.

23. 1 id. at 86.

24. 1 id. at 83 .

25. I id. at 84-85; Michez Foucault, Power and Strategies, reprinted in Power/Knowledge, supra note 13 , at 134,140 .

26. 1 Foucault, The History of SeXuality, supra note 16 , at 85 .

27. I id.

28. 1 id. at 83,85 .

29. 1 id. at 84-85.

30. Foucaulr, Truth and Power, supra note 13, at 121.

31. 1 Foucault, The History of Sexuality, supra note 16 , at 87.

32. 1 id. at 88-89; see also Foucault, Truth and Power, supra note 13, at 121.

33. 1 Foucault, The History of SexualtTy, supra note 16, at 90-91.

34. 1 id. at 90. 
cepts-in Foucault's term, a new "analytics of power"35_Foucault sought to trace historically the development of new "mechanisms" or "technologies of power" that operate outside the sphere of sovereignty and are "irreducible to the representation of law."36

\section{B. The Analytics of Power}

Foucault's "analytics of power" challenges the conception of power as a purely negative or repressive force. ${ }^{37}$ For Foucault, power is productive: "it produces domains of objects and rituals of truth." 38 Foucault does not trace power back to a single point, the point of sovereignty. ${ }^{39}$ Rather, he contends that power relations are omnipresent and diffused throughout society as "the immediate effects of the divisions, inequalities, and disequilibriums which occur" in social relationships. ${ }^{40}$ Thus, rather than analyzing power relations from the perspective of the sovereign, Foucault's "microphysics of power"41 emphasizes "power at its extremities ... those points where it becomes capillary ... its more regional and local forms and institutions." 42 These "infinitesimal mechanisms" of power "each have their own history, their own trajectory, their own techniques and tactics." 43 Beginning from these dispersed points, one can conduct an "ascending analysis of power" investigating how local techniques and tactics of power are linked to "more general powers or economic interests." 44

In displacing the traditional notion of power as sovereign command, Foucault emphasizes that power relations include not just the application of force, but also resistance. For Foucault, the very existence of power relations "depends on a multiplicity of points of resistance."45 Resistance, understood as the "irreducible opposite" in the exercise of power, can take various forms-per-

35. 1 id. at 82 (internal quotation marks omitted). Foucault generally refused the term "theory" of power. See, e.g., id. ('The aim ... is to move less toward a 'theory' of power than toward an 'analytics' of power ...."); Foucaurt, Critical Theory/Intellectual History, supra note 13, at 38 ("I in no way construct a theory of Power."). Foucault insisted on this point to avoid converting "power" into a substantive entity, "Power," whose properties a "theory" of power would purport to explain. 1 FouCAULT, THE HISTORY OF Sexuality, supra note 16, at 92-93. Thus, his remark in introducing his analytic of power: "[o]ne needs to be nominalistic, no doubt: power is not an institution, and not a structure; neither is it a certain strength we are endowed with; it is the name that one attributes to a complex strategical situation in a particular society." 1 id. at 93.

36. I Foucault, The History of SexualtTy, supra note 16 , at $89,109$.

37. See Foucault, Discipline and Punish, supra note 15, at 194 ("We must cease once and for all to describe the effects of power in negative terms: it 'excludes,' it 'represses,' it 'censors,' it 'abstracts,' it 'masks,' it 'conceals.' ').

38. Id.

39. 1 Foucault, THE History of SexualtTy, supra note 16, at 94 ("Power is exercised from innumerable points. ...'”.

40. 1 id.

41. Foucault, Disctiplne and Punish, supra note 15 , at 26.

42. Michel Foucault, Two Lectures, reprinted in Power/KNowledge, supra note 13, at 78, 96.

43. Id. at 99 .

44. Id.; see also 1 Foucault, The History of SeXualtry, supra note 16, at 94.

45. I Foucault, The History of SeXuality, supra note 16, at 95 ("Where there is power, there is resistance ...."). 
haps appearing as active opposition, but perhaps instead simply as "target, support, or handle in power relations." 46

As with power relations in general, Foucault's "microphysics of power" first investigates resistance at the local level. "[T]here is no single locus of great Refusal," 47 he maintains, but instead "a plurality of resistances, each of them a special case."48 For Foucault, to analyze power relations in a given society is to map the "network" or "dense web" 49 of forces-the interrelations among tactics, strategies, and technologies of power and resistance.

Foucault's historical studies set this conceptual framework into motion. In those works, particularly in Discipline and Punish, Foucault sought to historicize the relation between sovereign, monarchical power, and the specifically modern forms of power that emerged in the seventeenth century. Foucault calls these modern forms of power "disciplinary power."50 The opposition between law-as-sovereign-power, on one hand, and disciplinary power, on the other, is one of the key themes of Foucault's work on power. It will also turn out to be essential to Foucault's "expulsion of law" from modernity. ${ }^{51}$

\section{Sovereign Power and Disciplinary Power}

Sovereign, monarchical power, Foucault explains, operated through the periodic extraction of revenue or goods ${ }^{52}$ and through occasional but spectacular infliction of punishment by which the royal power exacted its revenge ${ }^{53}$ and "display[ed] itself in its murderous splendor." 54 Sovereign power is thus negative, extractive, and destructive. Disciplinary power, by contrast, employs surveillance, organization, and training to make its object, primarily the human body, more useful and productive. ${ }^{55}$ Disciplinary power is micropower: It works on the human body " 'retail,' individually," extending "an infinitesimal

46. 1 id.

47. 1 id. at $95-96$.

48. 1 id. at 96.

49. 1 id.

50. See Foucault, Two Lectures, supra note 42 , at 104 ("In the seventeenth and eighteenth centuries, we have the ... invention[] of a new mechanism of power . . . absolutely incompatible with the relations of sovereignty.").

51. See text accompanying notes $135-146$ infra.

52. I Foucault, The History of SeXualtry, supra note 16, at 136 ("[P]ower was exercised mainly as a means of deduction (prélèvement), a subtraction mechanism, a right to appropriate a portion of the wealth, a tax of products, goods and services, labor and blood, levied on the subjects. Power in this instance was essentially a right of seizure: of things, time, bodies, and ultimately life itself . ..."); see also Foucault, Two Lectures, supra note 42, at 104.

53. Foucault, Discipline AND PUNSH, supra note 15, at 130 (describing punishment under monarchical power as "a ceremonial of sovereignty" that uses "the ritual marks of vengeance"); $i d$. at 47-54 (examining torture and public executions as political rituals that vindicate the sovereign power by demonstrating the "dissymmetry between the subject who has dared to violate the law and the all-powerful sovereign who displays his strength").

54. 1 Foucault, The History OF Sexuality, supra note 16 , at 144.

55. E.g., Foucault, Discipline AND PUNISH, supra note 15, at 170 ("The chief function of the disciplinary power is to 'train,' rather than to select and to levy."); Foucaulr, Two Lectures, supra note 42 , at $104-05$. 
power over the active body." 56 Disciplinary power produces docile and useful bodies. 57

While Foucault acknowledges the use of disciplinary methods before the modern period, he argues that it was only in the seventeenth and eighteenth centuries that they became "general formulas of domination." 58 In Discipline and Punish, Foucault traces the spread of disciplinary technologies in the military, ${ }^{59}$ schools, ${ }^{60}$ workshops and factories, ${ }^{61}$ orphanages, ${ }^{62}$ hospitals, ${ }^{63}$ and prisons. ${ }^{64}$ Foucault describes three basic principles of disciplinary technology that were implemented in these institutions. "Hierarchical observation" involves arranging individuals (often architecturally) in order to ensure their continuous surveillance. ${ }^{65}$ "Normalizing judgment" uses small penalties and rewards to encourage norm-conforming behavior, such as punctuality and diligence. 66 "The examination" combines both of these techniques and places individuals under "a normalizing gaze, a surveillance that makes it possible to qualify, to classify, and punish."67 When performed systematically throughout a particular population, examinations create documentary records establishing what is "normal" for the population and arranging individuals according to those norms. ${ }^{68}$ In this way, individuals are constituted as objects of both power and of disciplinary technology's individualizing form of knowledge. ${ }^{69}$ Indeed, Foucault claims, "[t]he individual is . . . a reality fabricated by this specific technology of power that I have called "discipline." "70

For Foucault, Jeremy Bentham's "Panopticon" provides the exemplary instance of disciplinary technology. ${ }^{71}$ Bentham's celebrated prison design arranged inmate cells in a ring-shaped building surrounding a central tower. The cells were to be open to the tower and backlit, rendering the inmates "perfectly individualized and constantly visible"72 to the guard in the tower. Yet because the lighting and other architectural contrivances made the guard invisible to the inmates; they had always to assume they were always under the guard's watchful gaze, without ever knowing whether that was so. ${ }^{73}$ Thus, unlike the traditional prison design, the Panopticon enlisted the inmates in the operation of

56. Foucault, Disctpline ANd Punish, supra note 15 , at 136-38.

57. Id. at 138 .

58. Id. at 137.

59. Id. at $171-72,188$.

60 . Id. at $172-73,175-76,180-82,186-87,210-11$.

61. Id. at $174-75,210$.

62. Id. at 177-78.

63. Id. at $185-86,210,212$.

64. Id. at 200-02, 231-56.

65. Id. at $170-77$.

66. Id. at 177-84. "The workshop, the school, the army were subject to a whole micro-penality of time ... , of activity . . , of behavior. . . of speech . . , of the body . ., of sexuality." Id. at 178 .

67. Id. at 184; see also id. at 184-92.

68. Id. at 189-90. Medical examinations provide a paradigmatic example of this effect.

69. Id. at 192 .

70. Id. at 194.

71. Id. at 200 .

72. $1 d$.

73. Id. at 201. 
disciplinary power. $^{74}$ Such a system minimized the necessary number of guards while simultaneously multiplying the possibilities for surveillance. ${ }^{75}$

Foucault sees the Panopticon as a "figure of political technology" the "diagram of a mechanism of power reduced to its ideal form."76 As Bentham himself observed, the Panopticon's applications extended far beyond the prison setting. 77 Wherever continuous surveillance is required-for example, in mental institutions, schools, workshops, poorhouses, and hospitals ${ }^{78}$ - this "marvelous machine" can produce "homogenous effects of power."79

Panoptic mechanisms, according to Foucault, became detached from particular institutions, such as prisons, and came to "circulate" throughout the social body. ${ }^{80}$ Disciplinary institutions, such as schools and hospitals, developed techniques for surveillance of the population beyond their walls. ${ }^{81}$ Foucault describes the extension of panoptic technologies as the "swarming"82 of disciplinary mechanisms and the "formation of a disciplinary society."83 Ultimately, Foucault suggests, the network of these disciplinary institutions and practices form a "carceral archipelago," a "great carceral continuum" 84 in which "frontiers between confinement, judicial punishment and institutions of discipline" disappear. ${ }^{85}$

\section{Bio-power}

In the closing pages of History of Sexuality, Volume I, Foucault incorporates his account of disciplinary power into a more general concept: "biopower," or, the "power over life." 86 Bio-power, Foucault says, includes both disciplinary power over individual bodies ("anatomo-politics") and "a bio-politics of the population."87 While disciplinary power concerns "infinitesimal" details of bodies and their arrangements, 88 bio-politics addresses more global

74. Id. at 202-03.

75. See id. at 203. As Foucault puts it, the Panopticon turned the inmates into "the principle of their own subjection." Id.

76. Id. at 205.

77. Id. at 206.

78. Id. at $202,205$.

79. Id. at 202 .

80. Id. at $205-07,211$.

81. Id. at 211-212 (describing school officials' examination of pupils' home situations, medical observation of the population at large, and social workers' monitoring of poor persons' life conduct).

82. Id. at 211 .

83. Id. at 216.

84. Id. at 297.

85. Id.; see also id. at 298 ("[T]he prison transformed the punitive procedure into a penitentiary technique; the carceral archipelago transported this technique from the penal institution to the entire social body."); $i d$. at 228 ("Is it surprising that prisons resemble factories, schools, barracks, hospitals, which all resemble prisons?").

86. 1 Foucault, The History of SeXualtTy, supra note 16, at 139-40 (discussing the origins of bio-power).

87. 1 id. at 139.

88. Foucault, Disciplne and Punish, supra note 15, at 137; see also 1 Foucault, The HisTORY OF SEXUALITY, supra note 16, at 145-46 (referring to "infinitesimal surveillances" and a "micropower concerned with the body"). 
matters, such as "the problems of birthrate, longevity, public health, housing, and migration." 89

Sexuality is strategic terrain for bio-power, Foucault argues, because it brings together bio-power's two "poles of development": discipline of the body and regulation of the population. Located "at the pivot of the[se] two axes," 90 sex provides "a means of access both to the life of the body and the life of the species." 91 The regulation of sexuality thus involves disciplinary control, such as examinations, surveillance, and the "meticulous orderings of space,"92 as well as more "comprehensive measures, statistical assessments, and interventions aimed at the entire social body or at groups taken as a whole." 93

Foucault historicizes this notion of population in his later work on "governmentality."94 From the sixteenth century onward, Foucault argues, political thinkers became increasingly aware that "population has its own regularities, its own rate of deaths and diseases, its cycles of scarcity" and its own "specific economic effects." 95 Management of these problems required the creation of a distinctive form of rationality-an "art of government" or "raison d'état."96 Foucault describes this form of "governmental rationality" -in Foucault's neologism, "governmentality" - as a power over all and each that simultaneously individualizes and totalizes. ${ }^{97} \mathrm{He}$ traces the development of this form of political rationality from its origins in antiquity and early Christianity, to the seventeenth-century cameralist police state, to early liberal society, and finally to contemporary neo-liberal trends. ${ }^{98}$

\section{E. "Power/Knowledge"}

As the foregoing account of discipline and bio-power suggests, Foucault drew a close connection between the exercise of power and the production and deployment of knowledge. Power is productive, and one thing it produces is knowledge. Foucault writes:

89. 1 Foucault, The History of SeXuality, supra note 16 , at 139-40.

90. 1 id. at 145 .

91. 1 id. at 146.

92. 1 id. at 145 .

93. 1 id. at 146

94. See Michel Foucault, Governmentality, in ThE Foucault EfFect: Studies IN GoverNMENTALITY 99-101 (Graham Burchell, Colin Gordon \& Peter Miller eds., 1991); see also Michel Foucault, Omnes et Singulatim: Towards a Criticism of 'Political Reason' (Oct. 10 \& 16, 1979), reprinted in 2 The TarNer Lectures on Human Values 223 (Sterling M. McMurrin ed., 1981).

95. Foucault, Governmentality, in The FoucAult EFFECT, supra note 94, at 99.

96. P. 76. "[T] $]$ he correct principles for the organisation of the state came to be seen as immanent; the strength, economic and military, of the state itself became the goal of, and justification for, state action."

97. See Foucault, Omnes et Singulatim, supra note 94, at 226-27; see also Colin Gordon, Government Rationality: An Introduction, in THE FouCAULT EFFECT, supra note 94, at 1, 2-3 ("Government as an entity could concern the relation beteen self and self, private interpersonal relations . . . . relations within social institutions ..... and finally relations concerned with the exercise of political sovereignty.")

98. See generally Foucault, Omnes et Singulatim, supra note 94. 
Perhaps, too, we should abandon a whole tradition that allows us to imagine that knowledge can exist only where the power relations are suspended and that knowledge can develop only outside its injunctions, its demands and its interests .... We should admit rather that power produces knowledge . . . ; that power and knowledge directly imply one another; that there is no power relation without the correlative constitution of a field of knowledge, nor any knowledge that does not presuppose and constitute at the same time power relations. ${ }^{99}$

For Foucault, power thus produces knowledge, and at the same time, it produces "the individual as the effect and object of power, ... . effect and object of knowledge."100 "Human sciences" such as psychology, psychiatry, and criminology developed in the context of disciplinary power, Foucault suggests, particularly in the "ignoble archives" of the examination, "where the modern play of coercion over bodies, gestures and behavior has its beginnings."101 In turn, those sciences remain "profoundly enmeshed in social structures," 102 producing "truths" useful in the exercise of power. "[T] ruth," Foucault writes, "isn't outside power, or lacking in power .... Truth is a thing of this world: it is produced only by virtue of multiple forms of constraint. And it induces regular effects of power."103

But just as power always implies resistance, so do the "discourses" of power/knowledge enable counter-discourses of resistance. ${ }^{104}$ Foucault describes this potential reversibility as "the tactical polyvalence of discourses."105 In other words, a particular discourse "can be both an instrument and an effect of power, but also a hindrance, a stumbling-block, a point of resistance and a starting point for an opposing strategy."106 For example, the medical discourse that made "the homosexual" a category and object of regulation "also made possible the formation of a 'reverse' discourse: homosexuality began to speak in its own behalf, to demand that its legitimacy or 'naturality' be acknowledged, often in the same vocabulary, using the same categories by which it was medically disqualified."107 To underscore the close connection between power and knowledge, Foucault describes the production of truth in military and political language: He refers to the "régime of truth" and a society's " 'general

99. Foucault, Discipline and Punish, supra note 15 , at 27.

100. Id. at 192 .

101. Id. at 191; see also id. at 305 (explaining that the diffusion of penitentiary techniques throughout society contributed to the rise of the human sciences); Mrchel Foucault, On Power, reprinted in Polmics, PHILOSOPHY, CUrTURE, supra note 13, at 96, 106 ("[T] $]$ he birth of the human sciences goes hand in hand with the installation of new mechanisms of power.").

102. Foucault, Truth and Power, supra note 13, at 109.

103. Id. at 131 .

104. 1 Foucault, The History of SeXuality, supra note 16, at 100-02.

105. 1 id. at 100 .

106. 1 id. at 101. Elaborating on this theme Foucault states:

Discourse transmits and produces power; it reinforces it, but also undermines and exposes it, renders it fragile and makes it possible to thwart it. In like manner, silence and secrecy are a shelter for power, anchoring its prohibitions; but they also loosen its holds and provide for relatively obscure areas of tolerance. ... There is not, on the one side, a discourse of power, 1 id. and opposite it, another discourse that runs counter to it.

107. 1 id. 
politics' of truth,"108 including the "battle about the status of truth and the economic and political role it plays." 109

\section{F. "Genealogy" as "History of the Present"}

An important aspect of Foucault's work involved mapping the "tactical polyvalence of discourses" and tracing the transformations of "régimes of truth." Foucault usually described this project as "genealogy,"110 self-consciously borrowing the term from Nietzsche's Genealogy of Morals. ${ }^{111}$ Genealogy is not a search for the present in the past, nor is it an investigation of the past for its own sake."12 In Foucault's paradoxical phrase, genealogy is a "history of the present."113 The genealogist diagnoses a current situation, selecting an existing " 'ritual of power' or 'political technology of the body,' " and then inquires how it "arose, took shape, [and] gained importance."114 The genealogist does not assume that the technology or ritual is the same, or has the same meaning, in both past and present.

Consider, for example, Foucault's discussion of the confession in History of Sexuality, Volume I. Foucault begins from the premise that since the Middle Ages the confession has provided "one of the main rituals we rely on for the production of truth." 15 But the confession has "undergone a considerable transformation" 16 since the thirteenth century, when the Church first made it a duty for believing Christians. ${ }^{17}$ Confessional techniques have spread beyond the Christian confessional to become "employed in a whole series of relationships: children and parents, students and educators, patients and psychiatrists, delinquents and experts."118 Modern confession generates different "motivations and effects" and has assumed new forms: "interrogations, consultations,

108. Foucaurt, Truth and Power, supra note 13, at 131-32.

109. Id. at 132.

110. Earlier in his career, Foucault described his researches as "archaeologies." See, e.g., MicheL Foucault, The Archaeology of KNowledge (A.M. Sheridan Smith trans., 1972); Michel FouCault, The Birth of the Clinic: An Archaeology of Medical. Perception (A.M. Sheridan Smith trans., 1973); Michel Foucault, The Order of ThIngs: AN ARChafology of the Human Sciences (R.D. Laing ed., Vintage Books 1973) (1971). But because Hunt and Wickham rely almost exclusively on Foucault's "genealogical" works, I will not address the relation between "genealogy" and "archaeology." The interested reader should consult DREYrus AND RABinow, supra note 13, at 44-100 (explaining Foucault's archaeological method), 104-17 (discussing the relation between Foucault's genealogical and archaeological methods); Michael Mahon, Foucault's Nietzschean Genealogy: Truth, POWER, AND THE SUBJECT 101-06, 113-19 (1994).

111. Friedrich Nietzsche, ON the Genealogy of Morals (Walter Kaufmann \& R.J. Hollingdale trans., Vintage Books 1967) (1887). See Michel Foucault, Prison Talk, in Power/KNownEDGE, supra note 13, at 37, 53 ("If I wanted to be pretentious, I would use 'the genealogy of morals' as the general title of what I am doing.'); see also Michel Foucault, Nietzsche, Genealogy, History, reprinted in LANGuage, Counter-memory, Practice: Selected Essays and Interviews 139 (Donald F. Bouchard ed., Donald F. Bouchard \& Sherry Simon trans., 1977).

112. Dreyfus \& Rabnow, supra note 13, at 119.

113. Foucaut, Discipline AND PUNISH, supra note 15 , at 31 .

114. Dreyfus \& RaBnow, supra note 13 , at 119.

115. 1 Foucault, The History of SeXuality, supra note 16 , at 58.

116. 1 id. at 63 .

117. 1 id. at 58,60 .

118. 1 id. at 63 ; see also 1 id. at 68. 
autobiographical narratives, letters."119 A "confessional science" has developed, Foucault argues, a discourse "not of sin and salvation, but of bodies and life processes-the discourse of science."120 The relation between the confession then and the confession now resembles one of ancestry or descent more than one of identity.

Foucault's genealogies have a critical function. They serve not to "discover the roots of our identity" or our institutions, but to render both identity and institutions vulnerable to criticism. ${ }^{121}$ Consider, for example, the genealogy of punishment Foucault develops in Discipline and Punish. The book, significantly subtitled "The Birth of the Prison," seeks to undermine our belief that prisons are the inevitable form of punishment. Foucault argues that the systematic use of imprisonment as punishment is a relatively modern development, going back no further than the nineteenth century. ${ }^{122}$ He reviews two technologies of punishment prevalent in the century before the "birth of the prison"first, public torture and execution, then the reformers" "picturesque"123 "theatres of punishment"124_emphasizing the different functions punishment was thought to serve in those eras. ${ }^{125}$ Foucault presents the arguments against imprisonment that seemed decisive even a few years before the triumph of the prison, arguments that still resonate today. ${ }^{126}$ Immediately after the triumph of the prison system, and ever since, Foucault argues, it "was denounced ... as the great failure of penal justice," 127 because it fails to reduce the crime rate,
119. 1 id. at 63 .
120. 1 id. at 64 .
121. Foucault, Nietzsche, Genealogy, History, supra note 111, at 162.
122. See Foucault, Discipline ANd PUnsh, supra note 15, at 115-17.
123. Id. at 114 .

124. Id. at 102-14 (describing the evolution of punishment prior to the dramatic expansion of systematic imprisonment). The theater of punishment involved forcing the criminal to circulate publicly, bearing the signs of his crime for all to read and remember:

At the crossroads, in the gardens, at the side of roads being repaired or bridges built, in workshops open to all, in the depths of mines that may be visited, will be hundreds of tiny theatres of punishment. Each crime will have its law; each criminal his punishment. It will be a visible punishment, a punishment that tells all, that explains, justifies itself, convicts: placards, different-coloured caps bearing inscriptions, posters, symbols, texts read or printed, tirelessly repeat the code.... [T] hey should all, according to a strict economy, teach a lesson: that each punishment should be a fable. ... The great terrifying ritual of the public execution gives way, day after day, street after street, to this serious theatre, with its multifarious and persuasive scenes.

Id. at 113 .

125. For example, the public execution served to vindicate the sovereign and to display his power to the populace. Id. at 109. For their part, reformers tried to deter crime, by punishments to counteract the forces thought to cause particular crimes, id. at 106-07, and by educating the public about the laws and the connection between crimes and punishments. Id. at 107-14.

126.

[I]t is incapable of corresponding to the specificity of crimes. ... [I]t has no effect on the public. . . . [I]t is useless, even harmful, to society: it is costly, it maintains convicts in idleness, it multiplies their vices. ... [T] and ... there is a risk of exposing prisoners to the arbitrary will of their guards.... [T] of depriving a man of his liberty and of supervising him is an exercise of tyranny. . . It is obscurity, violence and suspicion.

Id. at 114-15 (internal citations omitted).

127. Id. at 264. 
causes recidivism, and creates career criminals. ${ }^{128}$ Thus, for Foucault, the prison's rise and continued existence are problems in need of justification, not evident social necessities. ${ }^{129}$

The critical edge of Foucault's genealogies appears, further, in their tendency to trace institutions or practices back to ignoble ancestry, much as Nietzsche traced morality back to "shameful origins."130 In discussing the development of a "science of sex," for example, Foucault notes the centrality of confessional practices and remarks that "[s]ince the Middle Ages, torture has accompanied [the confession] like a shadow, and supported it when it could go no further: the dark twins."131 Foucault thus suggests that the confession is genealogically linked to the project of controlling the body. Similarly, Foucault speculates that the human sciences' "birth" lies in the "ignoble' archives" of disciplinary power. ${ }^{132}$ A genealogical approach to history, Foucault writes, "teaches how to laugh at the solemnities of the origin ... . $[\mathrm{H}]$ istorical beginnings are lowly ... derisive and ironic, capable of undoing every infatuation."133 Genealogy deflates claims to disinterestedness and scientificity. ${ }^{134}$

\section{FoucAult's "EXPULSION OF LAw"}

So far I have mentioned law only in connection with the juridical model of power-the foil to Foucault's analytics of power. But what role does law play within Foucault's analytics of power? How is it related to disciplinary power and bio-power? In short: What role does Foucault assign law in modern societies?

A straightforward reading of Foucault's writings on power suggests, as Hunt and Wickham observe, that Foucault tends to "expel law from any significant role" in modern society. ${ }^{135}$ The argument for this "expulsion thesis" is remarkably simple.

The first part of this argument is the link Foucault consistently establishes between law, on one hand, and sovereignty and the "juridical" conception of

128. Id. at 264-71.

129. Id. at 120; see also id. at 271-82 (suggesting an explanation for the prison's survival, beginning from the assumption that its failures were useful).

130. Foucault, Nietzsche, Genealogy, History, supra note 111, at 141 \& n.6; see Thomas Flynn, Foucault's Mapping of History, in The CAMBRIDGe Companion to Foucault 28, 35-36 (Gary Gutting ed., 1994).

131. I Foucault, The History of SeXuality, supra note 16, at 59.

132. Foucault, Disicipline ANd Punish, supra note 15, at 191; see also note 101 supra and accompanying text.

133. Foucault, Nietzsche, Genealogy, History, supra note 111, at 143.

134. As Foucault explains:

Genealogies are ... not positivistic returns to a more careful or exact form of science. They are precisely anti-sciences. ... We are concerned ... with the insurrection of knowledges that are opposed ... to the effects of the centralising powers which are linked to the institution and functioning of an organised scientific discourse within a society such as ours. ... [IIt is really against the effects of the power of a discourse that is considered to be scientific that the genealogy must wage its struggle.

Foucault, Two Lectures, supra note 42, at 83-84.

135. P. 34. 
power, on the other. ${ }^{136}$ As noted above, ${ }^{137}$ Foucault presents law as the sovereign's prohibitory command to an obedient subject, backed ultimately by the sword. For Foucault, "power-law" is "power-sovereignty."138

The second part of the argument is the opposition Foucault establishes between modern power and sovereign power. Foucault's analytics of power attacks the "juridical" model, in which power is essentially negative and prohibitory. In Foucault's view, power is omnipresent in society, not located exclusively in the relation between sovereign and subject, and it is productive, not merely negative. The specifically modern form of power, Foucault contends, is disciplinary power, and disciplinary power, he says, is "absolutely incompatible with the relations of sovereignty."139 Disciplinary power, Foucault says, is "the antithesis of that mechanism of power which the theory of sovereignty described," 140 and accordingly, it is "irreducible to the representation of law."141 Thus disciplinary power, he suggests, is a "sort of counterlaw."142 An understanding of modern power relations, Foucault contends, must "no longer take law as a model and a code"; instead, we must "cease to conceive" of power "in terms of law, prohibition . . . and sovereignty."143

One could multiply the quotations from Foucault, ${ }^{144}$ but the point would be the same: By linking law to sovereignty, Foucault's analytics of power tends to expel law, and his historical analysis of disciplinary power confirms this expulsion. As Hunt and Wickham observe, Foucault in these passages "presents law as being essentially premodern."145 While law may "linger[ ] on in the doctrine of sovereignty," with its ideological role of masking power, "[i]n the real world of power, law has been supplanted"146 by disciplinary power and biopolitics.

As Hunt and Wickham observe, in other passages Foucault suggests a more complicated picture of modern law. Sometimes, rather than "counterposing law and discipline," Foucault "draw[s] attention to the interaction and interde-

136. P. 40.

137. See text accompanying notes 22-32 supra.

138. 1 Foucault, The History of SeXualiry, supra note 16 , at 90.

139. Foucault, Two Lectures, supra note 13, at 104.

140. Id.

141. I Foucault, The History of Sexuality, supra note 16 , at 89.

142. Foucault, Disicipline AND Punish, supra note 15 , at 222.

143. I Foucault, The History of Sexuality, supra note 16 , at 90.

144. See, e.g., 1 id. at 89 ("[T] he juridical system ... is utterly incongruous vith the new methods of power whose operation is not ensured by right but by technique, not by law but by normalization .... We have been engaged for centuries in a type of society in which the juridical is increasingly incapable of coding power, of serving as its system of representation."); id. at 90 ("[W]e must break free of ... the theoretical privilege of law and sovereignty .... We must construct an analytics of power that no longer takes law as a model and code."); Michel Foucaurt, Power and Sex, reprinted in Polmics, PhilosoPHY, CuLTURE, supra note 13, at 110, 123 ("[W]e know very well that law does not describe power."); Foucault, Two Lectures, supra note 13, at 102 ("[W] should direct our researches on the nature of power not towards the juridical edifice of sovereignty, the State apparatuses and the ideologies which accompany them, but towards domination and the material operators of power.... We must escape from the limited field of juridical sovereignty and State institutions, and instead base our analysis of power on the study of the techniques and tactics of domination.").

145. P. 44.

146. P. 56. 
pendence of disciplinary practices and their legal framework."147 As an example, Hunt and Wickham cite Foucault's suggestion that the eighteenth century development of "a system of rights ... egalitarian in principle was supported by these tiny, everyday physical mechanisms, by all those systems of micropower that are essentially non-egalitarian and asymmetrical that we call the disciplines."148 Here, Foucault suggests that law and discipline are complementary, not fundamentally opposed: By guaranteeing submissive bodies, " $[t]$ he real, corporal disciplines constitute[ ] the foundation of the formal, juridical liberties." 149

Still, as Hunt and Wickham note, we should not make too much of this passage. As they point out, Foucault seems here to treat modern constitutionalism as merely an ideological form, a masking of "real" and "corporal" power with "formal" and "juridical" liberties. ${ }^{150}$ One may be skeptical about what constitutional democracies actually deliver, yet still consider democracy more than an ideological screen for disciplinary power. ${ }^{151}$ Further, Foucault's imagery - disciplinary power underlies the modern legal framework-seems misleading. Disciplinary power, such as an employer's power, seems to presuppose a whole set of legal categories and rules concerning who may exercise such power and how they may exercise it. ${ }^{152}$ Law thus does not simply rest atop the "foundation" of disciplinary power; it helps constitute disciplinary power. ${ }^{153}$ Finally, there remain the many passages, cited above, in which Foucault presents law and discipline as fundamentally opposed.

The source of the problem is easy to identify. Foucault equates law with the idea of negative, prohibitory, sovereign command, while at the same time he distinguishes modern forms of power from sovereign command. Foucault's second point seems clearly correct: The model of sovereign command does not accurately describe many modern relations of power. The solution to the "expulsion" problem, then, must be to weaken the link between law and sovereign command.

Foucault's own work, however, offers few resources for reformulating his notion of law as sovereign command. As Hunt and Wickham observe, "law

147. P. 47.

148. Foucault, Discipline and Punsh, supra note 15, at 222.

149. Id.

150. Pp. 61-62 (quoting FoucAult, DisCIPLINE AND PUNish, supra note 15, at 222).

151. See p. 62. Hunt and Wickham explain their disagreement with Foucault as follows: Modem democracy and constitutionalism has to be approached as a dilemma, that is, with a genuine doubt about its achievements and its potential for realising participatory democracy. The deficiency in Foucault is not that he problematises constitutional democracy, but that his ld. answer comes down so unambiguously on one side of the dilemma.

152. See Jonathan Simon, "In Another Kind of Wood": Michel Foucault and Sociolegal Studies, 17 LAw \& Soc. INQUIRY 49, 50-51 \& n.4 (1992).

153. Cf. Robert W. Gordon, Critical Legal Histories, 36 Stan. L. Rev. 57, 103 (1984) ("[I]n practice, it is just about impossible to describe any set of 'basic' social practices without describing the legal relations among the people involved-legal relations that don't simply condition how the people relate to each other but to an important extent define the constitutive terms of the relationship, relations such as lord and peasant, master and slave, employer and employee, ratepayer and utility, and taxpayer and municipality."). 
[wa]s never one of [Foucault's] major objects of inquiry."154 Despite Foucault's many detailed genealogies of other "specialised professional discourses," he "simply takes no account of the internal and substantive aspects of the development of legal thought." 155 The result of this inattention is an inadequate conception of law, as Hunt and Wickham recognize. Foucault's "imperative conception of law,"156 in which law is the sanction-backed command of the sovereign, "equates 'law' with the punitive forms of criminal law."157 This conception, like Austin's positivist notion of "law as command of the sovereign," has a fatal weakness: It omits the "great bulk"158 of law, as H.L.A. Hart pointed out against Austin. ${ }^{159}$ For example, rules governing property and contract provide a framework for bargaining and other activity, but they neither command nor forbid particular actions. Nor are rules governing court procedure or allocating authority among governmental entities best described as commands from sovereign to subject. In short, Foucault's conception of law as sovereign command is too crude a tool for understanding modern law.

Hunt and Wickham deserve great credit for diagnosing the "expulsion of law" from Foucault's account of power and identifying the inadequacy of his conception of law. ${ }^{160}$ Their discoveries, however, raise a further difficulty. If Foucault lacks a plausible theory of law and never seriously investigated legal matters, why should contemporary legal scholars bother themselves with his writings? What in Foucault's work makes him relevant to legal studies, if his understanding of law was so primitive?

This difficulty is not as insuperable as it might first seem. Legal scholars who borrow from disciplines such as economics or game theory, for example, routinely appropriate work that does not itself contain a developed, built-in theory of law. In these interdisciplinary borrowings the question is not whether the appropriated theory has itself gotten law right, but whether it contributes anything useful to ongoing work in legal scholarship. Similarly, even if Foucault's explicit discussions of law lead to a dead end, we might still ask whether the Foucaultian concepts, themes and methods outlined in Part I are useful or illuminating for legal scholarship. This interpretation of Foucault would focus less on the sentences in his work containing the word "law," and

\section{P. viii. \\ 155. P. 68. \\ 156. P. 59.}

157. P. 59; accord DUNCAN KENNEDY, The Stakes of Law, or Hale and Foucault!, reprinted in Sexy Dressing ETc. 83, 119 (1993) ("Foucault is unmistakably a 'criminalist' in his understanding of law").

158. P. 60.

159. Cf. H.L.A. Hart, The Concept of Law (1961).

160. Hunt first published the expulsion of law thesis in 1992. See Alan Hunt, Foucault's Expulsion of Law: Toward a Retrieval, 17 LAw \& Soc. INQUIRY 1 (1992). This 1992 article was a revision of a working paper Hunt prepared in 1991. See Alan Hunt, Why Did Foucault Get Law So Wrong? Reflections on LAW, Power AND SOVEREIGNTY (Carleton University Department of Sociology and Anthropology Working Paper 91-4). In that same year, Duncan Kennedy published a similar critique of Foucault's "criminalist" conception of law. See Duncan Kennedy, The Stakes of Law, or Hale and Foucault!, 15 LEGAL STUD. FORUM 327 (1991), reprinted in KENNEDY, supra note 157. 
more on the possible connections between other aspects of Foucault's work and the concerns of contemporary legal theory.

Hunt endorsed this sort of interpretation in a 1992 article on which Foucault and Law extensively relies. ${ }^{161}$ There, Hunt described his approach as "an exercise in retrieval."162 After diagnosing Foucault's expulsion of law, Hunt sought "to recuperate much in his thought that is suggestive and illuminating for our understanding of the complex role of law in the constitution of modern society." 163

In Foucault and Law, Hunt and Wickham at first suggest a similar approach. "This book," they say in the introduction, "aims ... to demonstrate the pertinence of Foucault for contemporary issues in legal studies."164 My contention in the next section, however, will be that the aim of "retrieving" Foucault competes with another goal: the inauguration of a "new subdiscipline"165 called "the sociology of law as governance."

\section{Hunt and Wickham's "Soctology of Law as Governance"}

Hunt and Wickham begin the second half of their book by briefly reviewing Foucault's later essays and speeches on "governmentality," in which he sought to describe historically the modern concern with "population."166 Hunt and Wickham suggest in passing that "[i]n this phase of [Foucault's] work the earlier expulsion of law from modernity is significantly modified." 167 But they also acknowledge and quote passages from Foucault to opposite effect, ${ }^{168}$ and in any event, they do not linger over the details of Foucault's investigations into "governmentality."

From this point on, the authors concern themselves with the construction of their new subdiscipline, leaving the connections to Foucault's work largely implicit. In their words, they "do not spend much energy . . . relating [their] points directly to Foucault." 169

\section{A. The Principles of "Law as Governance"}

"Governance," the central concept of Hunt and Wickham's new subdiscipline, is an extraordinarily broad notion. It includes "any attempt to control or manage any known object," where an "object" may be "any phenomenon which human beings try to control or manage."170 The authors' definition of "governance" combines three definitions: "'government,' as in the rule of a

161. Hunt, supra note 160 .

162. Id. at 3.

163. Id.

164. P. viii.

165. P. 122.

166. P.55; see also text accompanying notes 94-98 supra.

167. P. 55.

168. See, e.g., p. 52 ("[T]ime and again [Foucault] stresses the essentially non-legal character of his expanded conception of government."); p. 53 (quoting Foucault's remark that "[w]ithin the perspective of government, law is not what is important').

169. P. 75.

170. P. 78. 
nation-state, region, or municipal area; 'self-government,' as in control of one's own emotions and behavior; and 'governor,' as in devices fitted to machines to regulate their energy intake and hence control or manage their performance."171 The first two definitions emphasize the breadth of "governance," while the last suggests its "machine-like" quality. ${ }^{172}$

Hunt and Wickham devote most of the latter half of their book to an elaboration of various "principles" relevant to the "sociology of law as governance." They articulate four "content principles" applying generally to governance, ${ }^{173}$ four corollary content principles applying to the special case of "law as governance,"174 and four "method principles."175 The authors then offer a brief (sixpage) illustration of these principles at work. ${ }^{176}$

\section{Content principles.}

According to the first general content principle, governance is a cyclical and perpetual process. Attempts at control are inevitably incomplete, leading to further attempts at control. ${ }^{177}$ Governmental attempts to control unemployment, for example, are only partially successful at best, and the process is unending. ${ }^{178}$ Governance continues not in spite of incompleteness or failure, Hunt and Wickham contend, but because of it. ${ }^{179}$

According to Hunt and Wickham's second principle, governance involves "power," "politics," and "resistance."180 By "power," Hunt and Wickham mean "the technical process whereby all aspects of social life are produced, the process of governance. ... [and] the techniques which make up that process."181 The focus, therefore, is on technique and process, not on outcomes or distributions. ${ }^{182}$ By "politics," they mean that techniques of governance are always at least potentially contestable. ${ }^{183}$ Because any existing technique of governance has been selected from among alternatives, every operation of governance involves politics-the contestation of governance. ${ }^{184}$ In this sense,

171. Pp. 78-79.

172. See pp. 80-83 (providing mechanical metaphors for "governance").

173. Pp. 79-97.

174. Pp. 102-16.

175. Pp. 117-26.

176. $\mathrm{Pp}$. 127-32. Throughout their discussion, Hunt and Wickham present these individual principles as one-sentence pronouncements, followed by examples and explanation. The two sets of content principles share identical formulations, except that in the second set the authors insert the words "law" as" before the word "governance." They then repeat, with different examples, much of what they said about the corresponding principle of governance in general. I focus here on the general principles of governance, then explain what is particular about "law as governance."

177. P. 80.

178. Pp. $79-80$.

179. P. 80. Here Hunt and Wickham could have mentioned Foucault's account of the perpetual process of prison reform. See text accompanying notes 122-129 supra.

180. P. 80.

181. P. 81. Notice that Hunt and Wickham define governance in terms of power, and power in terms of governance. The same problem appears in their alternative characterization of power as "the vast array of governing techniques which come together in various combinations as governance." P. 81 .

182. Pp. 81-82.

183. Pp. 82-83.

184. Pp. 82-83. 
they say, even the "governance" of "a piece of fruit" implicates politics. ${ }^{185}$ As in Foucault, resistance, "the "counter-stroke' to power,"186 is part of any situation of governance: "Power and resistance are together the governance machine of society." 187

Throughout their discussion of power, politics, and resistance, Hunt and Wickham emphasize their interest in "mundanely productive" power, not spectacular acts of power or resistance. ${ }^{188}$ They note that in contrast to "many years of political theory and analysis," their "underlying picture of society ... reflects [a] predominance of passive and mundane politics." 189 While "the politics associated with governance sometimes feature 'exploitation' and 'repression," "190 these are not, in Hunt and Wickham's view, the "types of contest which predominate in the world."191 The authors refer instead to "advantage" and "disadvantage" in describing political outcomes, reserving terms such as "oppression" and "exploitation" for extraordinary cases. 192

The third and fourth content principles require less explanation. "Governance always involves knowledge," Hunt and Wickham maintain. ${ }^{193}$ Whether this knowledge is simple or complex, formal or informal, depends upon the objects in question and the context of governance. Finally, "[g]overnance is always social": 194 both in the sense that its objects and techniques are limited to those that are socially available, ${ }^{195}$ and in the sense that it "bind[s] societies together,"196 however provisionally, unstably, and incompletely. ${ }^{197}$ At the same time, this binding "involves social division."198 That is, while governance may form communities, communities always exclude others as strangers; while governance may establish moralities, moralities imply transgressors who must be excluded. 199

Because law is necessarily a form of governance, these four principles apply to the study of law.200 To capture the particularity of law as a form of governance, however, Hunt and Wickham first propose a definition of law, then apply the principles to the special case of law as governance.

185. P. 82.

186. P. 83 (emphasizing the "strong technical, machine-like connotations" of Foucault's words).

187. Id.

188. Pp. 81,84 .

189. P. 84.

190. Id.

191. Id.

192. Pp. 84-85.

193. P. 87.

194. See pp. 92-94. Hunt and Wickham mention Foucault's notion of "the social" as a regulatory theme invented in the 19th century, pp. 92-93, but opt for the more standard sociological notion of the "social" as "that which pre-exists individuals in consideration of the collective actions of individuals." P. 92.

195. Pp. 92-94.

196. P. 92.

197. P. 94.

198. P. 92.

199. See pp. 94-95. Hunt and Wickham acknowledge this principle's roots in both Durkheim and Foucault. Pp. 92-95.

200. See p. 99. 
The authors' definition of law, like their definition of governance in general, is extremely broad. Law is to be understood operationally - that is, not as a set of rules or texts, or as a collection of institutions, but as "doing[s]."201 Law can be found everywhere-not just in courts or legislatures and not only when particular rules or texts are at issue. Adapting Weber's famous definition of law, ${ }^{202}$ Hunt and Wickham see law as "an operation [that] involves a calculation ... towards conformity with an historically received norm or the avengement of a violation of such a norm,"203 where specialized personnel (such as judges) stand ready to enforce the norm. ${ }^{204}$ Within this broad definition, the operation of law includes not only the prosecution, conviction, and punishment of theft, but also the theft itself, its reporting, and its investigation: All involve the requisite calculation. ${ }^{205}$ Likewise, the act of keeping books in a business firm is an operation of law, because it "involves daily calculations by company officials, using a quite formal means of accounting calculation, towards conformity with an historically received norm of corporate accountability."206 These examples, the authors suggest, indicate "the pervasiveness of law in the modern era" and illustrate that law operates "as part of the routine practice of daily life."207

In their account of law, as in their general account of governance, Hunt and Wickham emphasize the "technical" and "mundane" nature of most governance. ${ }^{208}$ Law, like other forms of governance, implicates power, politics, and resistance, but conflict is not necessarily dramatic. Again, Hunt and Wickham distance themselves from terms such as "oppression" and "exploitation."209

\section{2. - Method principles.}

The "field" of investigation thus bounded, Hunt and Wickham introduce four "method principles." These "rules of the game" follow "the spirit of Durkheim" and his Rules of Sociological Method.210

201. Id.

202. See Max Weber, Economy and Society: An Outtine of Interpretive Sociology 34 (Guenther Roth, Claus Wittich eds., Ephraim Fischoff, Hans Gerth, A.M. Henderson, Ferdinand Kolegar, C. Wright Mills, Talcott Parsons, Max Rheinstein, Guenther Roth, Edward Shils, \& Claus Wittich, trans., 1968) ("An order will be called ... law if it is externally guaranteed by the probability that physical or psychological coercion will be applied by a staff of people in order to bring about compliance or avenge violation.").

203. P. 100

204. Id.

205. Pp. 100-01.

206. P. 102.

207. Id.

208. See, e.g., pp. 104, 106, 128-29 ("technical"); pp. 104, 106, 108, 110, 130-31 ("mundane").

209. Pp. 106-07 (arguing that only long-term studies of legal politics can reveal the structural disadvantage called "oppression").

210. Emile Durkheim, The Rules of Sociological Method (Steven Lukes, ed., \& W.D. Halls, trans., 10th ed. Free Press 1982) (1895); see pp. 116-117. Hunt and Wickham assert that "Foucault refuses to be pinned down on matters of method." P. 117. This claim is questionable. Consider, for example, Foucault's outline of his "analytics of power" in History of Sexuality, Volume I. He presents that analytics in a section entitled "Method" that describes "four rules to follow." 1 FoucAuLT, THE HistoRY OF SEXUALrry, supra note 16, at 98-102. While he allows that these rules are not "methodological imperatives" but "at most . . . cautionary prescriptions" introduced in a "preliminary way," 1 id. 
According to the first method principle, "[t]he sociology of law as governance works to compile social facts in a genealogical manner."211 The authors view this method of investigation as a comparative, historical approach that gathers "facts from different societies and different eras."212 The investigation begins with some present situation or problem (abortion, for example). It then highlights the contingent nature of prevailing governance techniques, by emphasizing alternative techniques of governance, and by illuminating the particular (also contingent) social conditions that make some techniques more plausible than others. ${ }^{213}$ Like Foucault, Hunt and Wickham design their genealogies "to disturb the obviousness of the present" by describing it as "a collection of contingencies."214

Under the second method principle, these genealogies must be detailed and meticulous: "The only tools employed by the sociology of law as governance are attention to detail and careful generalisation."215 The study of law as govemance is not a predictive science. ${ }^{216}$ It does not identify "causes" or produce "explanations"217_ just details and "careful generalisations."218 When in doubt whether a generalization is sufficiently careful, Hunt and Wickham counsel, compile more detail. 219

Even if the adherent to sociology of law as governance complies faithfully with the requirement of care and detail, the authors lament, the work may still be used for ignoble purposes.220 Among the potential abuses, Hunt and Wickham identify political uses by either side in a political controversy. ${ }^{221}$ The third method principle therefore requires that uses of research must be distinguished from "[t]he basic production work" itself. ${ }^{222}$ Nevertheless, according

at 98 , it still seems misleading to say he "refuses to be pinned down on matters of method." Similarly, in Power/Knowledge, Foucault presents his approach to power in terms of "methodological precautions." Foucault, Two Lectures, supra note 42, at 96-103. And in Discipline and Punish, Foucault lists the "four general rules" of method he follows in that book. Foucaurt, Disciplnse AND PunISH, supra note 15 , at 23 . One might criticize Foucault for changing methodological principles from one work to the next, but the same criticism applies to Hunt. See note 222 infra.

211. P. 117. Hunt and Wickham hasten to point out that they mean "social facts" in Durkheim's sense, and that Durkheim's term "fait social" is perhaps better translated as "social doing." P. 118.

212. P. 119.

213. See pp. 118-20.

214. P. 119.

215. P. 120.

216. P. 121 .

217. P. 124.

218. See p. 121.

219. P. 122.

220. See id.

221. P. 123 (using abortion as their example).

222. P. 122. Hunt's prior work on Foucault did not draw such a sharp separation between scholarship and political uses of scholarship. In his 1992 article, on which the book's exposition and critique of Foucault draws heavily, Hunt saw a more intimate connection between scholarship and political commitment:

An altemative politics must ground itself in the project of working through the linkages between multiple fields of struggle that Foucault's crucial insight into the dispersal and proliferation of the sites of power makes possible. The retrieval of law from the expulsion to which Foucault subjects it is one of the most important components of such a project.

Hunt, supra note 160 , at 38 . 
to the fourth method principle, practitioners of the "law as governance" approach must still consider those uses. The sociology of law as governance is "reflexive" in precisely this respect. The subdiscipline must take itself as an object of its own investigations, ferreting out misuses by practitioners and others. 223

\section{B. Evaluating Hunt and Wickham's "Sociology of Law as Governance"}

One can read Hunt and Wickham's plea for a "sociology of law as governance" in either of two ways: as a free-standing research proposal, or as the completion of a book that seeks to "demonstrate the pertinence of Foucault for contemporary issues in legal studies."224 While my main interest is in whether the authors have shown the relevance of Foucault to modern legal theory, I want to note, briefly, two reservations about whether the governance approach will prove as "fruitful"225 for future research as the authors suggest.

One reservation concerns the image of scholarly activity I discern in Hunt and Wickham's sketch of the governance approach. The authors' tactic of promulgating eight principles for the subdiscipline's practitioners to follow makes the governance approach seem more rule-bound and dogmatic than Hunt and Wickham likely intended. Further, the authors' explication of the subdiscipline's method principles makes day-to-day research work seem oppressive and sterile. The sociologist of law as governance must compile details with "great care and exactness," 226 then carefully attempt generalizations from this mass of details. When in doubt whether a generalization is sufficiently careful, Hunt and Wickham caution, "further detail should be compiled before another generalisation is attempted."227 Hunt and Wickham use the expression "more and more details" no fewer than three times, in less than two pages. ${ }^{228}$ These repeated exhortations begin to sound like something more than reminders of acknowledged scholarly virtues. Considered together with the authors' sharp distinction between scholarship and the uses of scholarship, ${ }^{229}$ the laborious compilation of detail begins to seem an end in itself.

The second reservation concerns the way Hunt and Wickham choose to present the world of "governance." Their central metaphor presents govern-

Hunt and Wickham also seem particularly concerned that their work will be used to generate causal explanations or predictions. See p. 124. This concern contrasts with Hunt's emphasis, in his 1992 article, on the importance of causal analysis. See Hunt, supra, at 32 ("Foucault's epistemological wariness led him to avoid pronouncing on causality in his historical studies, thereby incapacitating himself from providing a satisfactory account of how specific discourses arose or how they came to prevail over rival discourses."); id. at 33 ("Those who are concerned, as I am, not to relinquish a concern with causality ... must add to our conceptual apparatus."); id. at 34 (endorsing "the strong Marxist concern with causality").

223. Pp. 125-26. Hunt and Wickham acknowledge, however, that no method "can ever be applied in a 'pure,' institutionally uncontaminated, apolitical way." P. 126.

224. P. viii.

225. Id.

226. P. 120.

227. P. 122.

228. Pp. $120-21$.

229. See text accompanying notes $220-222$ supra. 
ance as a "machine" 230 whose features, Hunt and Wickham repeatedly remind us, are "technical" and "mundane."231 The authors' "underlying picture of society," they say, "reflects [a] predominance of passive and mundane politics." ${ }^{232}$ So anxious are Hunt and Wickham to avoid charged terms, such as "struggle" and "exploitation,"233 that they describe even the hotly contested issue of "[r]esistance to or by the police" as "also a technical matter."234 While the authors assert that politics, power, and resistance are the leading concepts of the governance approach, these concepts flatten out in the metaphor of governance as machine. Politics indeed involves forces of power and resistance. But politics extends beyond the choice among techniques of control or management to include the contest among values and broader social visions. The image of governance as machine does not seem well-chosen to capture the richness and texture of political life.

Perhaps Hunt and Wickham's future work will depart from the metaphors and images of their proposal. Indeed, some aspects of this approach-such as the emphasis on law's ubiquity and the perpetual incompleteness of legal regulation-seem promising. Future uses of the "law as governance" approach, however, are not my main concern. More important, for present purposes, is the problem with which I closed my earlier discussion of Foucault's "expulsion of law": If Foucault's work lacks a plausible theory of law, in what sense can it be useful for legal scholarship? Does the authors' outline of law as governance explain how Foucault's work is, or may be made, useful to legal academics?

In my view, it does not. One difficulty is that in developing their "law as governance" approach, Hunt and Wickham stop speaking directly to legal academics. They describe their approach as a subdiscipline of the sociology of law, influenced principally by Durkheim ${ }^{235}$ and Weber, ${ }^{236}$ but also by Machiavellian political theory, ethnomethodological sociology, and Talcott Parsons. ${ }^{237}$ This appeal to the sociological tradition may speak to scholars working in sociology departments on the sociology of law. But what of legal academics, Hunt and Wickham's other intended audience? ${ }^{238}$ The authors themselves complain of the "intellectual insularity" that has excluded even Weber from the legal academic canon. ${ }^{239} \mathrm{How}$, then, can an appeal to the sociological tradition reach these same intellectually insular lawyers?

Hunt and Wickham further alienate their legal academic audience by describing their project as if it were wholly conventional and dated. They admit, for example, that their four method principles "make the sociology of law as governance look remarkably similar to many nineteenth-century sociological

230. See pp. 80-81, 82, 83, 104, 106.

231. See, e.g., pp. 104, 106, $128-29$ ("technical"); pp. 104, 106, 108, 110, 130-31 ("mundane").

232. P. 84.

233. See id.

234. P. 130.

235. E.g., pp. 92, 94-97, 100, 112, 114-20, 126, 132 (discussing Durkheim).

236. E.g., pp. 76, 99-100, 117, 126 (discussing Weber).

237. P. 78.

238. See p. vii.

239. Id. 
ventures," particularly those "British and continental sociological projects which sought to map a social terrain and which saw little difference between statistics and sociology."240 Despite having chosen to write a book on Foucault-a controversial figure on the contemporary intellectual scene-Hunt and Wickham close that book with an invocation of conventional sociological work and the past:

In many respects the sociology of law as governance's approach ... is not dramatically different from other sociological approaches .... [T] his is not a cause for concern; quite the reverse. In examining Foucault's work on law and in building a framework for a new sociology of law as governance out of this examination, we have been clear all along that the name Foucault does not signal an intellectual revolution. Rather, we have shown that it signals an opportunity to return to some nineteenth- and early twentieth-century sociological endeavors; hence our keenness to use Foucault's insights alongside those of Durkheim. The best way to use Foucault's work, we suggest, is an instrument for ground clearing, surveying and mapping; such is our approach to Foucault and law. ${ }^{241}$

This description of the project will not likely appeal to Hunt and Wickham's legal academic audience-those few academic lawyers curious enough to pick up a book about Foucault. The reader can't help but wonder why she worked through panopticism, power/knowledge, and bio-power, only to end up "return[ing] to some nineteenth- and early twentieth-century sociological endeavors," with Foucault useful only for "ground clearing, surveying and mapping." 242

The underlying problem is that the two halves of Foucault and Law fit together uneasily. The second half of the book develops a "new framework for the sociology of law."243 The first half, however, explores the work of a thinker who "does not have a theory of law. . . . because law [wa]s never one of his major objects of inquiry."244 As Hunt and Wickham recognize, rebuilding Foucault's work to include a plausible theory of law would be a difficult task in itself, and even a rebuilt Foucault would not have gotten Hunt and Wickham where they wanted to go. Thus, they disavow any intent to "construct a 'Foucaultian theory of law," "245 and in developing their subdiscipline's various content and method principles they relate their discussion "only occasionally" to Foucault. ${ }^{246}$ Foucault moves off-stage, and the project of constructing their new subdiscipline begins to take precedence over the authors" aim of "demonstrat[ing] the pertinence of Foucault for contemporary issues in legal studies."247

240. P. 126. They note their use of "genealogy" makes the comparison "somewhat inaccurate," but add that "in terms of the spirit of methodology, the comparison is accurate." P. 126.

241. P. 132.

242. Id.

243. P. viii.

244. Id.

245. P. viii.

246. P. 75.

247. P. viii. 
While I sympathize with the authors' refusal to construct a "Foucaultian theory of law," I wish they had tried to show more directly Foucault's relevance to contemporary issues in legal studies. Rather than outlining a "new approach" to the sociology of law, in which Foucault takes his place alongside Durkheim and Weber, Hunt and Wickham could have examined how Foucaultian concepts and themes are already at work in exemplary texts of legal scholarship, or considered how they might be put to use. This inquiry would not develop a general theory of law, Foucaultian or otherwise. But it might demonstrate more clearly and directly Foucault's relevance to the interests of at least some legal academics.

\section{Uses of Foucault in American Legal Studies}

Hunt and Wickham describe legal scholars' attention to Foucault as "marginal."248 In most instances, this description is literally accurate. Most of Foucault's appearances in legal scholarship are in footnotes, where he stays just long enough to create the impression that the author is familiar with European theory, then disappears without doing any work. ${ }^{249}$

Not all uses of Foucault fit this pattern, however. Some legal scholars have appropriated insights or concepts from Foucault; a few have sensed the deficiencies in, and sought to revise, Foucault's understanding of law. I want to discuss, briefly, two such appropriations of Foucault. These works, by exceptional scholars extraordinarily well-versed in theory, illustrate a point that Hunt and Wickham suggest: "Applying" Foucault to law, particularly if it means inserting Foucaultian concepts into legal argument, requires caution.

Mark Barenberg's article, Democracy and Domination in the Law of Workplace Cooperation, 250 focuses on the problem of "company unions" under the National Labor Relations Act. Barenberg seeks to illuminate this issue by examining the "technologies of power" management uses in exercising "disciplinary power" over the workforce. ${ }^{251}$ Barenberg connects this disciplinary power to law. For Barenberg, law is not external to or opposed to discipline, as Foucault often suggested; rather, by defining and regulating relations between labor and management, law influences the scope of the employer's disciplinary power, as well as the range of possible worker resistance.

Although Barenberg does not directly address Foucault's views on law, he seems to recognize that Foucault's work is lacking in that respect. He therefore presents his connection between law and discipline as a shift of emphasis in

248. P. vii.

249. We all know this kind of footnote; there's no reason to single anyone out as an example.

250. Mark Barenberg, Democracy and Domination in the Law of Workplace Cooperation: From Bureaucratic to Flexible Production, 94 Colum. L. Rev. 753 (1994).

251. Id. at 773 n.45 (citing Foucault, Two Lectures, supra note 42, at 104-06). Barenberg also refers to the "panoptic workplace," which employs a high-tech version of the methods Foucault discussed in Discipline and Punish. Id. at 909-10 (citing Foucault, Disciplne and Punsh, supra note 15); see also notes 72-79 supra and accompanying text. Discussing the "principle of visualization," Barenberg notes that a panoptic workplace design "leaves work stations open to the view of coworkers and managers," with "[w]orkers' performance data . . . publicly displayed and formally discussed." Barenberg, supra note 250 , at 910 . 
Foucault's account of power. Whereas Foucault "highlights the way in which power is 'locally' instituted," Barenberg "reemphasizes the legal realists' and positivists' familiar insight that the legal regime's coercive and ideological authority ultimately stands behind the employer's disciplinary regime."252 In fact, Barenberg establishes a closer connection between law and discipline than the words "stands behind" suggest. Disciplinary power, he argues, is ultimately "delegated" state legislative power. ${ }^{253}$ In constructing and enforcing workplace rules, Barenberg says, the employer engages in "private law-making," and the state stands ready to enforce the employer's sanctions for violations of the employer's law.254

But Barenberg's strategy of connecting Foucault's "analytics of power" to the realist notion of delegated power raises a problem. Presenting employer power as delegated state legislative power suggests that power is ultimately sovereign power, that disciplinary power in the workplace arises from the sovereign's decision to bestow a portion of its power upon the employer. In other words, Barenberg's attempt to outfit Foucault's analytics of power with a plausible theory of law leads Barenberg back to the "discourse of sovereignty" that Foucault's analytics of power expressly criticized.25s

A similar problem arises in Kendall Thomas's article, Beyond the Privacy Principle. ${ }^{256}$ Thomas relies heavily on Foucault's notion of power in arguing that the state action doctrine should cover "private" violence against gays and lesbians. ${ }^{257}$ Thomas first observes that Foucault's theory of power "urges us to abandon a unitary conception of power as that which is concentrated in the state."258 Modern power is dispersed power, and it is relational, not a thing or a "possessory interest."259 Even when power is not exercised by a formal state apparatus, Thomas argues, it may still be an "effective exercise of state power."260

252. Barenberg, supra note 250 , at 773 n.45.

253. Id.

254. Id.

255. See 1 Foucault, The History of SeXualtTy, supra note 16, at 93; see also text accompanying notes $21-49$ supra. Barenberg may escape from this problem, however, because his reference to "delegated state power" is unnecessary. To explain the connection between disciplinary power and law, he need only say exactly what he said before invoking "delegation": Law "ultimately stands behind the employer's disciplinary regime," to the extent the employer can have the resistant or disobedient employee hauled from the premises. The law, in other words, is an important element in the workplace power relation-important both to the exercise of power and to the possibility of resistance. Barenberg does not need to translate disciplinary power into delegated sovereign power to make this argument.

256. Kendall Thomas, Beyond the Privacy Principle, 92 ColuM. L. Rev. 1431 (1992).

257. See id. at $1478-90$.

258. Id. at 1480 (emphasis omitted).

259. Id.

260. Id. at 1481. Thomas relies for this point not on Foucault, but on Nicos Poulantzas. See id. (citing Nicos Poulantzas, State, Power, Socialism 36-37 (Patrick Camiller trans., Verso 1980) (1978)). This reliance is problematic. Despite Thomas's implication that Foucault and Poulantzas are allies on the question of state power, Poulantzas sharply criticizes Foucault's view of power, particularly state power. See Pourantzas, supra, at 149 ("One can deduce from Foucault nothing more than a guerilla war and scattered acts of harassment of power."). 
Tracing the connections between "private" violence and the state regulatory interest asserted in (so-called) homosexual sodomy statutes, 261 Thomas concludes that "the actual, concrete effect of these laws is to legitimize the lawless infliction of homophobic violence."262 Accordingly, he maintains, "violence against gays and lesbians perpetrated by other citizens" raises a constitutional issue, because such violence "represents the states' constructive delegation of governmental power to these citizens."263 As with Barenberg's attempt to connect law and disciplinary power, however, Thomas's idea of delegated state power is difficult to reconcile with Foucault. Once again, the attempt to incorporate Foucault's analytics of power into the legal context seems to lead us back to the discourse of sovereignty Foucault sought to escape.

Throughout I have been assuming that we must try, with Foucault, to avoid recourse to the discourse of sovereignty. But why did Foucault so arduously seek to escape that discourse? His main objection was that the language of sovereignty neither describes the techniques by which power is actually exercised nor focuses sufficiently on the effects of power. ${ }^{264}$ We mischaracterize power when we see it as following the single model of the legal command.265 And we misunderstand it when we seek it "in the primary existence of a central point, in a unique source of sovereignty from which secondary and descendent forms would emanate."266 Foucault's objection, in short, was that the language of sovereignty misdescribes power relations.

Thomas uses Foucault's analytics of power to make exactly this point in the context of American constitutional theory. Constitutional law sees "power in terms of possession," Thomas observes, but Foucault's work makes clear that this "highly formalistic conception of power . . . is too crude a conceptual resource for understanding the actual operation of political power in contemporary societies."267 This use of Foucault corresponds well to the impulse behind Foucault's analytics of power: We misunderstand modern power when we see it in terms of sovereignty and possession.

But Foucault proves less helpful for Thomas' ultimate purpose. Thomas seeks not only to describe the exercise of power in modern society, but to frame an argument within the discourse of constitutional law: that apparently private violence against lesbians and gays should qualify as "state action" for constitutional purposes. ${ }^{268}$ In advocating this position, Thomas shifts from the analytics of power to the discourse of constitutional law. "In assessing the constitutionality of these laws" he says, "I would argue that violence against gays and lesbians perpetrated by other citizens represents the states' construc-

261. Thomas, supra note 256 , at $1482-90$.

262. Id. at 1487 (emphasis deleted).

263. Id. at 1481-82.

264. See text accompanying notes 136-142 supra.

265. See, e.g., Foucaurt, Power and Sex, supra note 144, at 123 ("We know very well that law does not describe power.'); 1 Foucault, The History of SEXualtTy, supra note 16, at 92 ("By power, I do not mean ... a mode of subjugation which, in contrast to violence, has the form of the rule.").

266. 1 Foucaurt, The History of SeXuality, supra note 16 , at 93.

267. Thomas, supra note 256 , at 1478.

268. See id. at 1481-92. 
tive delegation of governmental power to these citizens."269 Thomas' use of the words "represents" and "constructive" shows that he is engaging in legal fiction: It is as if the state had delegated its power to the perpetrators of violence. He is employing, in other words, not Foucault's analytics of power, but a standard and "highly formalistic"270 technique of constitutional argument. Constitutional discourse, it seems, requires this formalism of Thomas, and it repels any simple insertion of Foucault's analytics of power.

It would not have surprised Foucault to find that legal discourse-or at least some forms of legal discourse-may be linked inescapably to notions of sovereignty. ${ }^{271}$ For Foucault, one discourse cannot necessarily be folded into another. One possible consequence may be that his work cannot always be simply "applied" directly in legal argument. Foucault designed his analytics of power to deemphasize the state, to show that the actual exercise of power is dispersed throughout the social order, not concentrated in the state apparatus. Constitutional law, by contrast, requires those challenging a particular exercise of power to attribute that power to the state. Further, even in private law contexts, the Realist-inspired strategy for making "private" power visible is to describe it as a constructive delegation of state power. ${ }^{272}$ Foucault's work operates more readily as a challenge to standard legal constructions of the world than it does as a direct intervention into conventional forms of legal argument.

A different way legal academics might use Foucault is to develop some of the themes he suggested without directly impressing him into service in legal argument. A good illustration of how Foucault might be used in this way is an article that never mentions Foucault: Reva Siegel's Reasoning From the Body: A Historical Perspective on Abortion Regulation and Questions of Equal Protection. ${ }^{273}$

269. Id. at 1481-82.

270. Id. at 1478 .

271. Nor do I think it would surprise Thomas, who is aware of the tension between Foucault's analytics of power and the state action doctrine. See texts accompanying notes 258-260, 267 supra.

272. As Joseph Singer summarizes the Realist strategy for exposing power behind the market: "The realists argued that the state is fundamentally implicated in all 'private' transactions .... By defining the rules of the market, the state determines the distribution of economic power and thus the distribution of wealth and income .... In the midst of every transaction sits the state, determining the relative bargaining power of the parties, and hence, to a large extent, the structure of "private' relations." Joseph William Singer, Legal Realism Now, 76 CAL. L. REv. 465, 495 (1988).

The classic Realist sources in this vein are Morris R. Cohen, Property and Sovereignty, 13 CorNELL L.Q. 8, 11, 12 (1927) (describing Lochner-style decisions as "the passing of a certain domain of sovereignty from the state to the private employer of labor" and characterizing property right as "sovereign power compelling service and obedience"); Robert L. Hale, Bargaining and Economic Liberty, 43 Colum. L. Rev. 603, 604 (1943) ("The owner ... can insist on other people keeping their hands off his products. Should he so insist, the government will back him up with force."); Robert L. Hale, Coercion and Distribution in a Supposedly Non-Coercive State, 38 PoL. ScI. Q. 470, 471 (1923) (describing enforcement of property right as government "forcing the non-owner to desist from handling [the thing owned], unless the owner consents"); Friedrich Kessler, Contracts of Adhesion-Some Thoughts About Freedom of Contract, 43 CoLum. L. REv. 629, 641, 640 (1943) (describing contract law as "delegat[ing] to individual citizens a piece of sovereignty which enables them to participate constantly in the law making process," but noting that under modern conditions freedom of contract means "the exercise of power by contract").

273. Reva Siegel, Reasoning from the Body: A Historical Perspective on Abortion Regulation and Questions of Equal Protection, 44 StAN. L. REv. 261 (1992). 
Siegel's topic-the regulation of abortion-links nicely to Foucault's notion of "bio-power." Regulation of abortion involves the regulation of women's bodies, the exercise of "power over life," with a view toward global issues of "population."274 Siegel traces the nineteenth century campaign to criminalize abortion to the power of the medical profession and its asserted knowledge of the scientific facts of reproduction. ${ }^{275}$ The arguments made on behalf of abortion restrictions, however, were not purely scientific, but rested in significant part on judgments about women's proper role-a polemic that was in self-conscious opposition to early feminist demands for reform of the marriage relation. ${ }^{276}$ Siegel discusses the peculiar hybrid of discourses the doctors accomplished, using the concept of "physiological sin" to condemn abortion in terms at once religious and scientific. ${ }^{277}$ She describes, further, the doctors' use of "populationist" notions to argue both that the nation's future depended upon a strong birth rate generally and that abortion among native-born Americans was responsible for "dangerously" rising percentages of immigrant and underclass children. ${ }^{278}$ These arguments, Siegel contends, are related genealogically to a continuing "physiological naturalism"279 in judicial reasoning about issues of gender and reproduction: While explicit judgments about women's proper role are no longer persuasive, judgments coded in the language of physiological difference may produce the same effect. ${ }^{280}$

Thus, without expressly invoking Foucault, Siegel manages to touch on many of his concerns: bio-power and the regulation of bodies for "populationist" purposes; the use of asserted scientific knowledge to exercise social power; the particular power of the medical profession; the "tactical polyvalnce" of discourses, both moral and scientific; and the tension between discourses of power and those of resistance. Like Foucault's work, Siegel's article is historical, but not antiquarian. Siegel brackets her historical account at both ends by discussing the contemporary issue that motivates her inquiry. ${ }^{281}$

This interpretation of Siegel's article suggests a strategy for appropriating Foucault's insights. Foucault offers, first and foremost, a way of elaborating the social and historical setting in which legal structures and communications operate. His account of the "network" or "dense web" 282 of social relations emphasizes the importance of knowledge, particularly expert knowledge, in the process of constituting, reproducing, contesting, and transforming relations of power. Foucault's polemical dismissals notwithstanding, law is both product and producer of this ceaseless process. Law, no less than the discursive prac-

274. See text accompanying notes 86-98 supra (describing Foucault's notions of bio-power and "population"); Siegel, supra note 273, at 296-97 (discussing the power of doctors over women's "reproductive conduct").

275. Siegel, supra note 273 , at 287-92.

276. Id. at 300-14.

277. Id. at 293-97.

278. Id. at 297-300; cf. 1 Foucault, The History OF SeXUAIITY, supra note 16, at 148-50 (discussing eugenic projects in the 19 th and 20 th centuries).

279. See Siegel, supra note 273, at 267-68 (defining "physiological naturalism").

280. See id. at 267-80, 323-47.

281. See id. at 262-80, 347-81.

282. 1 Foucault, The History of SeXualtry, supra note 16, at 96. 
tices Foucault analyzed in detail, provides resources both for the exercise of power and for resistance to power.

Understanding law in this way requires close attention not just to the content of legal communications, but also to their rhetorical tactics. It requires, also, examining law's relation to other social discourses-not just professional discourses, such as Foucault's favorite examples of psychiatry, medicine, and criminology, but perhaps also more general social discourses related to divisions such as race, class, gender, and sexual orientation. ${ }^{283}$ Seen in this way, Foucault's work suggests connections between legal scholarship and "cultural studies" approaches. ${ }^{284}$

As I suggested above, Foucault is less directly useful for the "normative" aims of legal scholarship. Foucault paid little attention to legal questions, and his descriptive, analytic approach seems in tension with prescriptive or normative forms of legal discourse. The deeper problem is that while Foucault's genealogies doubtless had a critical edge, Foucault never made clear his criteria of evaluation. Understood as social criticism, Foucault's work seems to remain parasitic on a normative theory, or at least a set of normative views, that he never made explicit. ${ }^{285}$ That is, while Foucault emphasized the productivity and ubiquity of power, refusing to posit a free, fully constituted subject liberated from power, his genealogies gain their critical edge from the sense that domination and subjugation are worth opposing. 286 Foucault's tendency to invert the traditional Enlightenment story of progressively greater freedom and autonomy - a tendency visible in his account of the rise of "disciplinary" or "carceral" society287 - seems still to trade on Enlightenment ideals, even in the genealogical gesture of mocking them. ${ }^{288}$

283. Siegel's article is a particularly good example of this technique. Her account of the nineteenth-century campaign to criminalize abortion describes both the attempt to make medicine speak directly to law and the connections between medical discourse and popular discourse concerning norms of gender, ethnicity, race and class. See Siegel, supra note 273, at 292 (noting tension between antiabortion doctors' presentation of "facts" of childrearing and prevailing gender discourse), 293-97 (describing doctors' synthesis of scientific and religious argument), 297-300 (tracing doctors' appeal to concerns of race, ethnicity and class), 300-04 (discussing doctors' argument that abortion is a crime against maternity), 304-08 (noting 19th century feminist demands for "voluntary motherhood" and attributions of abortion to conditions of sexual inequality), 308-11 (analyzing doctors' appropriation of feminist terms and metaphors in context of antifeminist polemic), 314-18 (describing legislative acceptance of doctors' arguments, including arguments based on concerns of gender, ethnicity and class). Siegel uses similar techniques in her account of "contemporary modes of reasoning about reproductive regulation." Id. at 324; see also id. at 324-31 (describing physiological reasoning in popular antiabortion arguments), 331-35 (noting physiological reasoning in judicial opinions concerning abortion, including Roe v. Wade), 335-47 (describing gender bias in fetal-protective regulation and noting apparent effects of gender, race and class on regulatory strategy).

284. See e.g., Susan S. Silbey, Making a Place for Cultural Analysis of Law, 17 LAw AND Soc. INQUIRY 39, $41-48$ (1992).

285. Nancy Fraser, Unruly Practices: Power, Discourse and Gender In Contemporary Critical Theory 50-51 (1989); Jürgen Habermas, The Philosophical Discourse of Modernity 282-86 (Frederick Lawrence trans., 1987) (describing Foucault's approach as "cryptonormativism").

286. See, e.g., FrASER, supra note 285, at 28; HABERMAS, supra note 285 , at 283-84.

287. See text accompanying notes $82-85$ supra.

288. Cf. Thomas McCarthy, The Critique of Impure Reason: Foucault and the Frankfurt School, in Critique and Power: Recasting The Foucault/Habermas Debate 243, 260 (Michael Kelly ed., 
My point here is not that Foucault is necessarily trapped in a fatal performative contradiction, or that he owes us some fully developed (humanistic) theory that explains which forms of power are worth resisting and which are not. My point, rather, is simply that to the extent legal scholars engage in "normative legal thought," 289 advocating some legal rule or outcome as appropriate or desirable, Foucault's work cannot be their only theoretical resource. To argue, for example, that violence against gays and lesbians amounts to unconstitutional "cruel and unusual punishment" requires an account of the meaning of this constitutional phrase. ${ }^{290}$ To argue that restrictions on abortion violate the Equal Protection Clause requires an interpretation of what constitutional "equality" means. 291

While Foucault of course does not speak directly to such issues, an encounter with his work nonetheless may be productive. For example, Siegel's constitutional argument against abortion-restrictive legislation draws from her genealogy of the state's interest in "potential life." Her account of the ancestry and development of "potential life" suggests that abortion-restrictive legislation rests upon constitutionally impermissible judgements about women's proper roles. ${ }^{292}$ And Thomas uses Foucault's work to characterize violence against gays and lesbians as an exercise of power, relativizing the distinction between action taken by government officials ("state action" narrowly construed) and action encouraged or permitted by the state ("state action" understood in a "functional" rather than "formal" sense). ${ }^{293}$ Thus, while Foucault's work may be in tension with the normative aims of legal scholarship, strategic appropriation of his work may exploit this tension productively.

To be sure, appropriating Foucault requires revision of some aspects of his work. The most obvious candidate for revision is Foucault's notion of law as sovereign command. The next most obvious candidate, in my view, is Foucault's occasional suggestion that modern society is a "disciplinary" or "carceral" society, a dystopian nightmare. Further, some of Foucault's fundamental substantive concepts-such as disciplinary power and biopowerspeak more directly to some areas of law than to others.

Still, as Hunt and Wickham observe, the point is not to construct a "Foucaultian theory of law," but rather to appropriate from Foucault what is useful.

1994) (noting that “it became clear to [Foucault] only in the 1980's that his form of critique also belongs to ... the 'semantic field' of Enlightenment discourse").

289. See Pierre Schlag, Normativity and the Politics of Form, 139 U. PA. L. REv. 801, 801-43 (1991) (describing the characteristics of "normative legal thought").

290. See Thomas, supra note 256, at 1487 (describing a "functional" interpretation of the Eighth Amendment).

291. See Siegel, supra note 273, at 351-54 (distinguishing between "antidiscrimination" and "antisubordination" values of the constitutional equality guarantee).

292. See id. at 347-81.

293. See Thomas, supra note 256 , at $1476-92$. 
HeinOnline -- 48 Stan. L. Rev. 480 1995-1996 